Gianluca Fiore'

(D) https://orcid.org/0000-0003-4647-1759

Davide Elia Bertani

(D) https://orcid.org/0000-0002-6179-5009

Mattia Marchi ${ }^{1}$

Ohttps://orcid.org/0000-0003-2970-1276

Graça Cardoso²

https://orcid.org/0000-0003-1756-0197

Gian Maria Galeazzi

- https://orcid.org/0000-0003-2706-3362

\section{Patient subjective experience of treatment with long-acting injectable antipsychotics: a systematic review of qualitative studies}

\author{
Experiência subjetiva do paciente no tratamento com antipsicóticos injetáveis \\ de ação prolongada: uma revisão sistemática de estudos qualitativos
}

DOI: $10.1590 / 0047-2085000000311$

\begin{abstract}
Objective: To gain a better understanding of how long-acting injectable antipsychotic (LAI) therapy is perceived by patients. Methods: A search for qualitative studies has been carried out on PubMed, Google Scholar, PsycINFO and PsycArticles, yielding 11 studies suitable for a review of qualitative studies. The reporting approach chosen was meta-ethnography, following the ENTREQ statement recommendations. Key concepts common to the different studies were extrapolated and then analysed in a systematic and comparative way. Results: Some recurrent issues were associated with LAls, such as fear of coercion, fear of needles and lack of knowledge about depot therapy. These topics are linked to each other and the patients most concerned about the disadvantages of LAls are those who are less informed about them, or who have experienced coercion and trauma during hospitalisation. On the other hand, patients who had already received LAls, and those who had a good therapeutic relationship with their healthcare providers expressed satisfaction with this form of treatment and its continuation. Conclusion: Long-acting injectable antipsychotics are a tool in the management of mental disorders, and a viable alternative to oral medication. Patients show curiosity towards this method of administration, but lack of knowledge is a common finding. Shared decision making about the use of LAls antipsychotics requires that patients receive accurate information and support for their decision regarding medication.
\end{abstract}

\section{KEYWORDS}

Antipsychotics, LAl, long-acting injectable, depot, qualitative research.

\section{RESUMO}

Objetivo: Compreender melhor de que forma a terapia com antipsicóticos injetáveis de ação prolongada (IAP) é percebida pelos pacientes. Métodos: Uma pesquisa por estudos qualitativos foi conduzida em PubMed, Google Scholar, PsycINFO e PsyArticles, resultando em 11 estudos adequados para desenvolver uma revisão de estudos qualitativos. A abordagem escolhida foi a metaetnografia, seguindo as recomendações da diretriz ENTREQ. Conceitos-chave comuns aos diferentes estudos foram extrapolados e analisados de forma sistemática e comparativa. Resultados: Alguns problemas recorrentes foram associados aos IAPs, como medo de coerção, medo de agulhas e falta de conhecimento sobre a terapia com medicação depot. Esses tópicos se conectam uns aos outros: os pacientes mais preocupados com as desvantagens dos IAPs são os menos informados a seu respeito ou aqueles que passaram por coação e traumas durante a hospitalização. Por outro lado, os pacientes que já receberam IAPs e aqueles que apresentam boa relação terapêutica com seus prestadores de assistência médica demonstraram satisfação com essa forma de tratamento e sua continuidade. Conclusão: Os antipsicóticos injetáveis de ação prolongada são um instrumento para a gestão de transtornos mentais e uma alternativa viável à medicação oral. Pacientes demonstram curiosidade em relação a esse método de administração, mas a falta de conhecimento é um fator comumente encontrado. A tomada de decisão compartilhada sobre o uso de antipsicóticos IAPs requer que os pacientes recebam informações precisas e apoio em suas decisões em relação à medicação.

\section{PALAVRAS-CHAVE}

Antipsicóticos, IAP, injetável de ação prolongada, depot, pesquisa qualitativa. 


\section{INTRODUCTION}

Psychotic disorders are a group of severe mental disorders, characterised by the presence of various combinations of symptoms such as delusions, hallucinations, disorganised behaviours, and cognitive, affective, and expressive impairment. Schizophrenia is the most known of this group of disorders, affecting up to $0.7 \%$ of the population (20 million people worldwide according to the Global Burden of Disease 2017 study) ${ }^{1}$. Schizophrenia is the 8th cause of DALYS (Disability-adjusted life years) in the 15 to 44 age group worldwide ${ }^{2}$ and causes important personal and economic costs, both for the individuals, their family and friends, and for society.

Since 1952, when the first antipsychotic chlorpromazine was marketed, antipsychotic drugs have become the main pharmacological intervention in the treatment of schizophrenia. Antipsychotics are available in various formulations, and in the 1960s prolonged-release antipsychotics, or long-acting injections (LAls), also known as depot, were introduced in clinical practice, delivered by intramuscular injection and gradually released, obtaining, at the steady state, therapeutic levels lasting between 2 and 4 weeks (recently a 3-monthly LAI has become available).

Up to $50 \%$ of patients with schizophrenia show partial or total lack of adherence to pharmacological prescriptions $s^{3-5}$. The causes of this phenomenon are complex and include patients' factors (preference, cognitive problems, personality, insight, relationship with the prescribing physician), the very characteristics of the drugs (such as side effects, treatment duration, little or no therapeutic efficacy) and stigma towards mental disorders and medications used to treat them ${ }^{6,7}$. Incomplete or total lack of adherence to treatment is associated with symptoms relapse, at times leading to hospital admission.

From the pharmacological point of view, LAls make it possible to skip first-pass metabolism, increasing the bioavailability of the drug ${ }^{8,9}$. The slow release of LAls also allows reducing the typical plasma fluctuations seen with oral therapy, which also may be linked to side effects ${ }^{10}$.

LAl therapy has traditionally been used as a strategy to address non-adherence to oral medication in psychoses, usually late in the course of the disorder, but recently it has been suggested that this formulation may also bring benefits when used earlier, or even after the first acute psychotic episode ${ }^{11}$. However, the use of LAls is still significantly lower than traditional oral formulations ${ }^{12,13}$. There may be different reasons limiting the use of LAls: lack of knowledge of this therapeutic formulation and of its potential, both by the patient and the prescribing physician; patients factors, such as fear of needles or injections; preference for less invasive methods of administration and perceived coercion regarding this method of administration; physicians factors, such as the concern that proposing LAI will negatively affect the therapeutic relationship for reasons similar to those reported by patients; fears and negative opinions of relatives and acquaintances of patients; lack of distribution and availability of medicines in hospital facilities; and from a general point of view, the lack of clear practice guidelines on the use of LAls.

Most of the studies concerning LAI are quantitative, and focus on data such as effectiveness, tolerability, side effects, adverse reactions and adherence to treatment. There is a limited number of qualitative studies which have investigated the subjective experience of users, family members and prescribers/administrators, and which have analysed the complex and multifaceted range of beliefs, ideas, feelings and knowledge that revolve around the topic of LAls use in psychosis. This study reviews qualitative studies about longacting injectable antipsychotic drugs with the aim to gain a better understanding of how LAls therapy is perceived by patients, to analyse the perceived pros and cons of treatment with LAls in comparison to oral medication and to investigate factors in favour of each particular method of administration based on the experience and opinions of patients.

\section{METHODS}

This systematic review was conducted in accordance with the recommendations of the ENTREQ (Enhancing transparency in reporting the synthesis of qualitative research) statement (the protocol has been registered on PROSPERO with ID code CRD42020181888).

\section{Eligibility criteria}

This study includes qualitative studies conducted in focus groups, structured or semi-structured interviews and case studies, which aimed to explore the subjective experience and attitudes of patients towards LAls. Mixed methods studies with a qualitative component were also included. Studies reporting only quantitative data (e.g. cross-sectional, case-control, cohort studies and clinical trials) were excluded. To be included, studies had to be written in English or Italian and conducted between 2000 and 2020. Reference lists of retrieved articles have also been searched. Studies only describing the views of clinicians or carers were not included.

\section{Search}

Repeated searches of the following electronic databases were conducted from March 2020 until 22 April 2020: PubMed (MEDLINE), PsycINFO, PsycArticles, Google Scholar.

The following search terms were used: ("neuroleptic" OR "atypical antipsychotic" OR "depot injection" OR "LAIs" OR "long-acting antipsychotic injections" OR "long-acting") AND ("attitude" OR "experience" OR "subjective" OR "opinion" OR "perception" OR "belief" OR "interpretation" OR "view" OR "perspective*") AND "qualitative". 


\section{Study selection and quality assessment}

A total of 220 records were retrieved and duplicates removed. Titles and abstracts of the remaining records were screened against inclusion criteria by one author (GF), involving another (DB) in case of uncertainty, and those found to be irrelevant were discarded. Full texts of the remaining records were obtained and reviewed by two authors (DB, GF) independently. In case of disagreement between the two reviewers, this was resolved by discussion until consensus was reached or, if disagreement persisted, they turned to a third reviewer who acted as an arbiter. Finally, 11 eligible studies were included in this review. Figure 1 shows the flow chart documenting the selection process.

The quality of the studies was assessed by two reviewers (GF and DB) using the Critical Appraisal Skills Programme (CASP) qualitative checklist (Critical Appraisal Skills Programme, 2018).

\section{Data extraction, analysis and interpretation}

Given the relatively small number of studies available, and the high conceptual density of these studies, a metaethnographic approach was selected as the research method of choice, following ENTREQ statement recommendations. Meta-ethnography is a specific type of meta-synthesis aimed at identifying and defining common "key concepts" across different studies, in order to summarise and uniform the themes and topics. This method has been identified and described by Noblit and Hare ${ }^{13}$, who describe seven successive steps: (1) Getting started: formulating a valid research idea. (2) Deciding what is relevant: determining the parameters of research and inclusion. (3) Reading the studies: carefully reading the selected material. (4) Determining how studies are related: identification and extraction phase of the key concepts forming the basis of the single studies. (5) Translating studies into each other: standardising key concepts by making them common to all studies through a comparative method. (6) Synthesising translations: development of a model capable of interpreting research findings. (7) Expressing the synthesis: processing and disclosure of results.

The analysis proceeded as follows: initially, the first (GF) and second reviewer (DB) thoroughly read all papers to obtain an overview of the issues covered. Then the two reviewers coded the data from each of the papers line by line. Following the meta-ethnographic approach, lists summarising authors' original findings, using their terms and concepts, were drawn up for each of the selected papers. At the bottom of each list, "key concepts" were identified. Having identified the main concepts emerging from each paper, a systematic search was undertaken to establish the presence or absence of these concepts in all the papers included. The aim was to compare findings between studies.

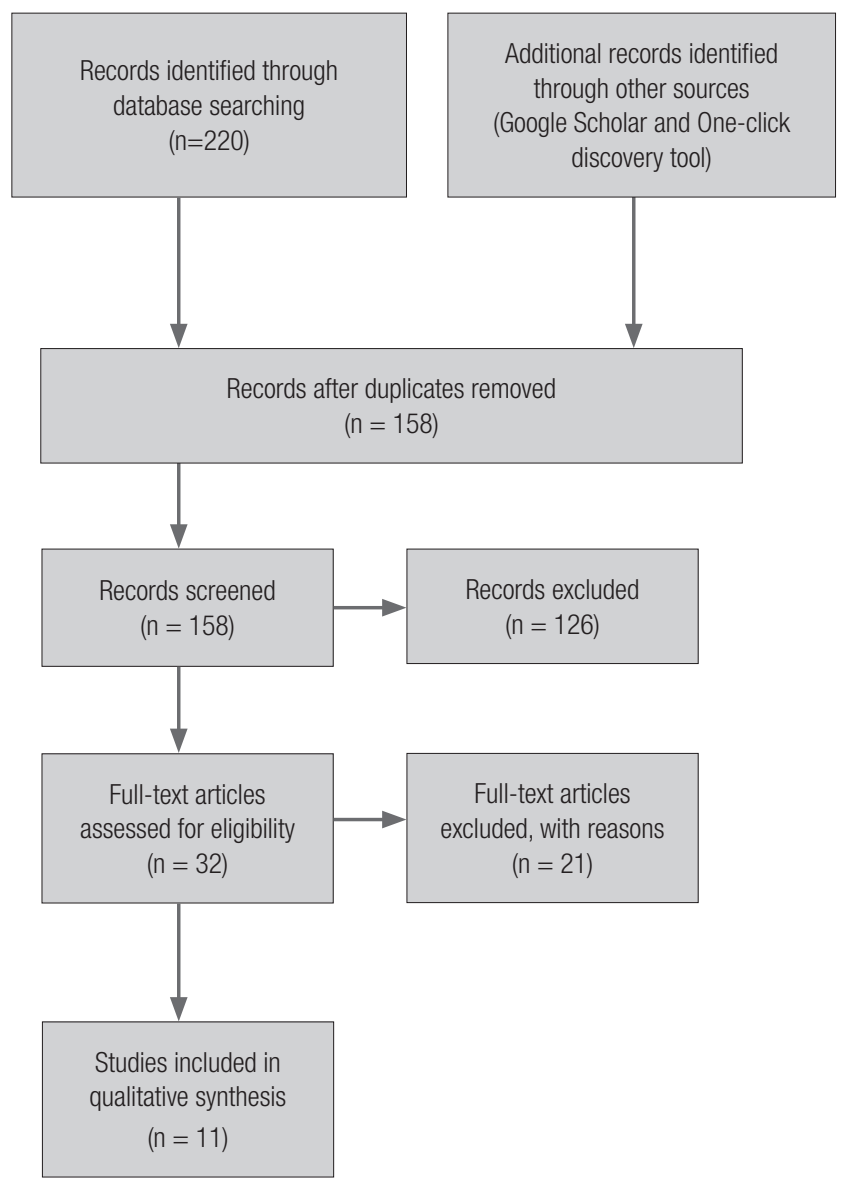

Figure 1. Flowchart of the inclusion process

\section{RESULTS}

Table 1 shows the main features of the studies included in this review.

The following eight key concepts emerged in reviewing the included papers.

\section{Advantages}

"I would like the injection because you only get it once a month. The good thing sells itself, but the bad thing walks its way to be bought." (Swahili proverb). (from Blixen et al., 2020)

Eight studies highlighted the advantages of the depot formulation. The most cited advantage was not having to remember to take medication every day ${ }^{14-20}$, an action that for some patients served as a daily reminder of their difficulties. Another advantage reported by patients was the sense of safety provided by the medication, perceived as a way of gaining control over the world around them and preventing dangerous situations ${ }^{15,21}$. Being treated with LAls was felt as a means to prevent relapses and hospitalisations ${ }^{16,20}$, as well as to acquire a greater sense of control over the disorder ${ }^{19}$. Some patients who had experienced this method of administration mentioned a reduced impact in terms of side 
Table 1. Summary of included studies

\begin{tabular}{|c|c|c|c|c|c|c|}
\hline Study & $\begin{array}{l}\text { Author } \\
\text { (years) }\end{array}$ & Country & Relevant aim of the study & $\begin{array}{c}\text { Sample } \\
\text { (n with experience with } \\
\text { LAls) }\end{array}$ & Data collection Methods & $\begin{array}{l}\text { CASP } \\
\text { score }\end{array}$ \\
\hline 1 & $\begin{array}{l}\text { Svedberg et } \\
\text { al. (2003) }\end{array}$ & Sweden & $\begin{array}{l}\text { To explore how the patients experience living with } \\
\text { long-acting depot antipsychotics }\end{array}$ & 11 patients (11 on LAls) & Open-ended interviews & 9 \\
\hline 2 & $\begin{array}{l}\text { De Diego Ruiz } \\
\text { et al.. (2019) }\end{array}$ & Spain & $\begin{array}{l}\text { To explore perception and opinion of outpatients } \\
\text { about LAls }\end{array}$ & $\begin{array}{l}18 \text { patients (9 on LAls, } 9 \text { on } \\
\text { oral medication) }\end{array}$ & $\begin{array}{l}\text { Semi-structured indepth } \\
\text { interview }\end{array}$ & 9 \\
\hline 3 & $\begin{array}{l}\text { Lin-Ling Chiu } \\
\text { et al. (2019) }\end{array}$ & Taiwan & To explore patient's' subjective experiences of LAls & $\begin{array}{l}14 \text { patients (14 had experience } \\
\text { with LAls) }\end{array}$ & $\begin{array}{l}\text { Semi-structured interview guide } \\
\text { with open-ended questions }\end{array}$ & 9 \\
\hline 4 & $\begin{array}{l}\text { Blixen et al. } \\
\text { (2020) }\end{array}$ & Tanzania & $\begin{array}{l}\text { To assess attitudes about medication and use of } \\
\text { LAls in a study implementing a comprehensive care } \\
\text { program for patients with psychosis }\end{array}$ & $\begin{array}{l}15 \text { patients, } 14 \text { caregivers, } 15 \\
\text { health-care providers }\end{array}$ & $\begin{array}{l}\text { Semi-structured interview and } \\
\text { focus groups }\end{array}$ & 8 \\
\hline 5 & $\begin{array}{l}\text { lyer et } \\
\text { al.(2013) }\end{array}$ & Canada & $\begin{array}{l}\text { To investigate perceptions of and attitudes toward } \\
\text { LAls among patients in Canada }\end{array}$ & $\begin{array}{l}34 \text { patients (14 experienced } \\
\text { LAls, } 9 \text { currently on LAls) }\end{array}$ & Focus groups & 8 \\
\hline 6 & $\begin{array}{l}\text { Das et al. } \\
\text { (2014) }\end{array}$ & UK & $\begin{array}{l}\text { To investigate attitudinal themes to LAls in patients } \\
\text { in an early intervention team }\end{array}$ & $\begin{array}{l}11 \text { patients ( } 3 \text { on LAls, } 4 \text { on } \\
\text { oral medication, } 4 \text { not currently } \\
\text { in treatment) }\end{array}$ & Semi-structured questionnaire & 9 \\
\hline 7 & $\begin{array}{l}\text { Potkin et al. } \\
\text { (2013) }\end{array}$ & USA & $\begin{array}{l}\text { To examine contemporary actual office visit } \\
\text { interactions between patients, caregivers, and } \\
\text { prescribers; to understand and characterize the } \\
\text { dynamic interaction between prescriber and patient } \\
\text { perspectives on the use of LAls in schizophrenia }\end{array}$ & $\begin{array}{l}60 \text { prescriber-patient } \\
\text { conversations, } 15 \text { patient in- } \\
\text { home visits, } 12 \text { telephone } \\
\text { in-depth interviews ( } 38 \text { on } \\
\text { LAls, } 22 \text { on oral medication) }\end{array}$ & $\begin{array}{l}\text { Qualitative and quantitative } \\
\text { analysis of recorded } \\
\text { conversations }\end{array}$ & 9 \\
\hline 8 & $\begin{array}{l}\text { Rankovic et } \\
\text { al. (2018) }\end{array}$ & Serbia & $\begin{array}{l}\text { To investigate problems with the administration of } \\
\text { LAls in patient with schizophrenia }\end{array}$ & $\begin{array}{l}5 \text { patients, } 2 \text { doctors, } 2 \text { nurses } \\
\text { (5 on LAls) }\end{array}$ & Semi-structured interview & 8 \\
\hline 9 & $\begin{array}{l}\text { Phillips et al. } \\
\text { (2007) }\end{array}$ & UK & $\begin{array}{l}\text { To examine the subjective experiences of people } \\
\text { receiving regular depot injections living in the } \\
\text { community }\end{array}$ & 10 patients ( 10 on LAls) & Semi-structured interview & 9 \\
\hline 10 & $\begin{array}{l}\text { Besenius et } \\
\text { al. (2012) }\end{array}$ & UK & $\begin{array}{l}\text { To ascertain the attitudes and experiences of } \\
\text { psychiatrists, nurse prescribers, and service users } \\
\text { with regard to the prescription of antipsychotic } \\
\text { medication, the route of administration, and the } \\
\text { extent of service users' involvement. }\end{array}$ & $\begin{array}{c}18 \text { patients, } 26 \text { psychiatrists, } \\
12 \text { nurses } \\
\text { (4 on LAls, } 14 \text { on oral } \\
\text { medication or not treated })\end{array}$ & Semi-structured interview & 8 \\
\hline 11 & $\begin{array}{l}\text { Robinson et } \\
\text { al. (2019) }\end{array}$ & USA & To understand barriers to use of LAl antipsychotics & $\begin{array}{l}23 \text { patients, } 16 \text { psychiatrists, } 3 \\
\text { nurses, } 23 \text { therapists, } 14 \text { clinic } \\
\text { administrators. }\end{array}$ & Semi-structured interview & 7 \\
\hline
\end{tabular}

effects, particularly drowsiness and weight gain, reduced anxiety and ease of administration ${ }^{19}$. Other patients also mentioned a sense of subjective wellbeing, associated with the reduction of psychiatric symptoms ${ }^{21}$. Svedberg described how patients saw the medication as a "balm" protecting them from sensations of pain and allowing them to interact with other people without being too frightened ${ }^{15}$.

\section{Disadvantages}

"The only thing I have complained about to my doctor is that the nurses who do the injections have different skill levels; some of them are skillful... but sometimes my wound was big, swollen, and even bled..." (from Chiu et al., 2019).

Ten out of eleven articles pointed out the disadvantages of long-acting antipsychotics. The most cited were pain in the injection site and fear of needles 15,17-19,21. The most common side effects at the site of injection were nodules, indurations, muscle granulomas, fibrosis, abscesses ${ }^{18}$. Although some studies $^{16,20}$ reported that it was mostly patients not treated with depot who feared needles and pain at the injection site, these disadvantages were mentioned in the articles that explore subjective perceptions of LAl-treated patients as well. Patients recalled the first injection as being painful and often traumatic ${ }^{15}$. As Potkin pointed out, patients who expressed deep concern about the injection were the ones who would not be administered LAls, regardless of the method of communication in use ${ }^{22}$. Patients would also prefer to always have the injection administered by the same health practitioner, although this may be incompatible with work shifts and injection clinic availability ${ }^{15,23}$. An additional preference was associated with the practitioner's gender, which some patients preferred to be the same as their gender ${ }^{16}$.

Patients reported another main disadvantage, which was the need to go in person to the LAI clinic for the injection. Although some patients thought it very convenient "to come once a month and just forget about it"20, sometimes a preference for oral therapy was expressed, for example, mentioning the need to leave work in order to go to the clinic. However, other patients preferred LAls so that they 
did not need to take oral medication at work and face their colleagues' curiosity ${ }^{21}$.

Taking LAls could also be problematic during travels and holidays, especially for patients treated with LAls every 2 weeks ${ }^{19}$.

Going to the LAI clinic also represented a risk to their privacy for some patients, and a motive for stigmatisation since LAl therapy was associated with severe types of psychiatric disorders ${ }^{16}$. Patients also reported concerns regarding the fact that the entire dose of antipsychotic for a long period was injected in one single administration ${ }^{20}$, causing them to fear that, if side-effects arose, they may have been prolonged for a month or more. However, regarding side-effects, different patients may have mentioned the same effect either as an "adverse effect" or a "benefit" depending on patients; for example, a patient reported that LAl-induced sleepiness helped her to regain energy to continue her work ${ }^{21}$. The negative perception of LAls was also due to the patients associating the injection with the idea of a medical procedure that is carried out against the patient's will, for example during an involuntary admission. This way, the coercive experience of a short-acting antipsychotic injection can be generalised to LAls formulation ${ }^{15,24}$.

\section{Information regarding LAls}

"What effects does that have, how does it work, if you can choose between that or an oral. That is, it is your right to be given more options and be informed, as with the pills, which, although I have not been informed, then, of the results, the effects it has. You have to be given all the information to choose, maybe. It should be with all the treatments, it would be positive, so you know." (from De Diego Ruiz et al., 2019).

The topic of "Information regarding LAls" emerges in 9 out of 11 studies. Robinson reports that most patients in his study were unaware of LAl antipsychotics as a treatment option, and only patients already treated with LAI knew what the treatment was about ${ }^{24}$. Although Blixten reports a widespread knowledge of LAls, the lack of information regarding LAI administration emerges in several studies $16,19,20$ and can partly explain the low rate of their prescription ${ }^{25}$.

Patients who are not treated with long-acting antipsychotics show curiosity towards this formulation and express a desire to know more. In several instances, this formulation has never been proposed or presented to them as an option ${ }^{16,19}$. Apart from psychiatrists, other sources of information on LAl antipsychotics are family members, nurses, social workers and other patients ${ }^{16,17}$. Phillips suggests that patients may feel embarrassed to ask for information regarding medication prescribed by their psychiatrist, whereas they feel more at ease in asking the same question to the LAl clinic nurse staff23.
Communication proves to be crucial in the choice of therapy. Several patients reported that physicians always seemed to be in a hurry and that little time was reserved for the clinical interview, during which the advantages and disadvantages of different treatment options could be discussed. When patients were introduced to the characteristics of the LAl formulation, many of them showed willingness to try it, as this would allow reducing their family's effort in keeping track of their medication intake ${ }^{24}$.

Discussing with patients about the side-effects of LAls is essential; this allows the creation of a good therapeutic relationship, which is helpful in preventing patient drop out ${ }^{17}$. Moreover, if patients are informed about LAl antipsychotics, then they can discredit common misconceptions about them; for example, since there is a common link between the parenteral administration of long-acting antipsychotics and the consumption of "street drugs" like narcotics 16,21 , patients could fear becoming addicted to LAls, because this medication is administered by injection.

\section{Therapeutic relationship}

"I'm not a psychiatrist, I put myself in their hands, so I don't know how much I can decide on that, so I think it's fair. There has to be a very good relationship between the psychiatrist and the patient for you to put your trust and say: well, what they are going to prescribe is going to be good for me." (from De Diego Ruiz et al., 2019).

Six articles discuss the theme of how the use of LAls affects the therapeutic relationship. Patients reported trust towards the therapeutic advice of their psychiatrists ${ }^{16,20}$; in particular, some of them confessed that they were too unwell to be totally involved in the therapeutic choice of long-acting antipsychotics, and later became grateful to their psychiatrists.

Robinson points out that a clinical interview lasts 15 minutes per patient on average, a duration which is defined as unavoidable considering the high patients-psychiatrist ratio in some contexts ${ }^{24}$. Given this constraint, patients do not feel emotionally supported in making decisions regarding their prescriptions. Moreover, patients are reluctant to change medications, and this results in it being more difficult to switch if it is not supported by their psychiatrist. During interviews, it was evident that patients would prefer to be advised on medications by their therapists in longer interviews (45-60 minutes per session) but therapists have no specific knowledge on the subject ${ }^{24}$. Therefore, this may represent a reason why the knowledge about LAls and their application remains limited.

Patients' longing for contact with health practitioners was witnessed by Phillips as regards the "secure place" represented by the LAI clinic. Patients define the LAI clinic as a "safe place to go", which furthermore ensures a sense of 
order in their lives. The presence of a named nurse can also create a safe space in which patients are allowed to explore and communicate their experiences ${ }^{23}$.

Potkin et al. point out that the discussions about LAls may develop following two different approaches: the "positive" one, that highlights LAls advantages and successful stories of other patients treated with LAl and the "punishing" one, aimed at improving adherence by using coercive tactics. It is however concerning that, regarding the decision to start the treatment with LAls, patients declared that they felt they did not have other choices ${ }^{17,19,24}$. In fact, when psychiatrists put aside the option of LAls, they mainly do so in order to preserve a healthy trusting therapeutic relationship ${ }^{22}$.

\section{Coercion}

"The only time I was ever on an injectable... was when I was hospitalized, for the psychiatric assessment or whatever, then I get away from the hospital and I get away from psychiatrists and I dropped my meds all the time. My experience wasn't good, I didn't learn from anyone, it was just something that was forced on me. I didn't have a choice in the matter... and when there was a choice, I chose not to take it." (from lyer et al., 2013).

The issue of coercion is addressed in 6 out of 11 studies. In most cases, psychiatrists decided type and dose of medication without checking with the patient or the caregivers, although participation in the choice may have varied depending on the severity of the disorder (with less severe cases being more involved in the choice) and the therapeutic formulation (patients were more involved when discussing LAls than oral therapy)22. In Ruiz's study, it appears that no patient felt forced to accept LAls medication, although indirect pressure from family members or caregivers to follow the doctor's instructions was reported ${ }^{19,20}$. Some patients reported that the drug was initiated during an exacerbation of the disorder, when they had no capacity to choose, and that trust in the doctor and the therapeutic alliance were very important during recovery in the decision to continue to take medication or not ${ }^{16}$. Many patients remembered the first injections as violent and painful, to the point of comparing them to rape or poisoning ${ }^{15}$. One patient reported how the feeling of coercion and loss of autonomy during the Community Treatment Order (CTO) was so detrimental and traumatic that once he regained decision-making capacity he refused to continue therapy with LAls; another patient stated that the same kind of experience enabled him to continue taking medications and prevent dropout ("I kind of felt like someone would be looking over my shoulder with the injectable, like it wasn't my choice") ${ }^{19}$.

\section{Openness towards LAls}

"I would like to get injections, even though it may be lifelong. I don't know. Anyway, taking injections all the time is necessary for my illness. This is my way of living. I'm not affected much by the side effects, so I think receiving injections is better for me and makes me clearer." (from Chiu et al., 2019).

The issue of compliance to LAls has been one of the most discussed topics and is covered in 10 studies out of 11. This topic is very close to the theme of the therapeutic relationship: most studies describe patient adherence as being strongly influenced by the bond they form with healthcare practitioners. It should be noted the majority of patients start receiving LAls during hospitalisation, experiencing feelings of anxiety and confusion, and external professional support is described as having fundamental importance. The topic of information is again central, since many patients report how the knowledge of LAls formulation came to them only in a late and partial way 16,19,20; some of them claim that they would have switched to LAls earlier, if only they had known the different therapeutic options ${ }^{16}$, while for others the refusal to switch to the LAI was dictated by the complete lack of information regarding the formulation ${ }^{19}$. Robinson describes how some patients, after receiving short-acting injections during CTO hospitalisation, had such a negative experience that they rejected the LAI because they did not know the differences between short and long-acting injections, and were unable to distinguish between them. In Rankovic's study, patients who switched from oral to LAI were very satisfied and reported that they would never go back to oral administration ${ }^{18}$. Cultural factors play a part in the subjective perception of LAl: in the Chiu study, conducted on 14 Taiwanese participants, it was found that Western medicines were perceived to be toxic to the body, and a monthly injection was considered less dangerous than a daily pill intake ${ }^{21}$. Another study shows that more than half of the patients had good adherence with LAl therapy, judging it necessary or feeling comfortable with it ${ }^{17}$. Noteworthy is the fact that the Blixen study shows that patients and caregivers considered themselves as aware of the positive effect and usefulness of the medication in achieving stability, while their very healthcare professionals perceived them as being misinformed, lacking interest and struggling to understand the importance of medication ${ }^{26}$.

\section{Stigma}

"One patient regarded LAls as being associated with stigma as evidenced by statements of the neighbours in the street who look at him differently." (from Rankovic et al., 2018).

Five out of eleven studies discuss the topic of stigma. This feeling of marginalization and discrimination can be perceived in the interaction with passer-by ${ }^{16}$, neighbours ${ }^{18}$ as well as potential romantic partners, and even with oneself ${ }^{26}$. For some patients, a stigma was related to medications (injections more than oral therapy), while for others a stigma was linked to the very perception of the disorder ${ }^{16}$, which led some patients to take their medication in secret, so as 
not to be discovered as being mentally ill. Injection therapy, however, can also be felt as facilitating recovery: some patients reported that the reduction in symptoms brought about by medication enabled them to build and improve interpersonal functioning, granted them the chance to find and maintain stable employment, to form a family, and to lead a "normal" and well-integrated life in society", diminishing the feeling of stigma, isolation and shame that frequently characterizes mental disorders ${ }^{27}$. According to the data collected in Ruiz's semi-structured interviews, patients' requests and suggestions about this topic were on the implementation of anti-stigma programs, aimed at increasing awareness and acceptance by the community, and spreading the idea that mental disorder is comparable to other disorders, and deserves the same treatment and respect.

\section{Road to recovery}

"Participants expressed that their lives had become more 'ordinary' and that they could identify themselves more as a 'normal' person". (from Svedberg et al., 2003).

Seven out of eleven studies dealt with the topic of recovery. For many patients, the improvement in symptoms granted by the intake of medications became an opportunity to regain autonomy and freedom of choice, returning to the 'normality' impaired by the disorder ${ }^{15}$. Psychosis in its acute form can be a very traumatic experience ${ }^{26}$, and it is described by patients as degrading and 'horrible', both for themselves and for their caregivers ${ }^{20}$. Therapy allows the regaining of self-mastery, counteracting the feeling of loss of control and anguish typical of the acute phases of the disorder ${ }^{19}$. Central themes are the recovery of family and work relationships. In the family environment, the emphasis is placed on the regained possibility to interact normally with relatives, to no longer be a source of concern for them ${ }^{21}$, and to feel less dependent. At work, many patients found an improvement in their attention, concentration and reasoning ${ }^{22}$, which allowed them to return to work with satisfying results.

The therapeutic relationship with the healthcare provider is the catalyst for the recovery process: Phillips describes how the figure of the doctor or nurse in charge of administering the LAl can be a reference point for the patient, that can support, empower and validate them as human beings throughout the healing process ${ }^{23}$.

\section{DISCUSSION}

The results of the present review show that there are recurrent themes emerging from qualitative studies of subjective experiences of patients receiving LAls. One of the most recurrent themes concerns the disadvantages of the long-acting formulation, especially in relation to the perceived coercion associated to this therapeutic strategy ${ }^{2,25}$, made worse by the feeling of loss of control over the timing of the administration ${ }^{28}$. The poor consideration of longacting formulations is shared by psychiatrists too, who tend to think that patients would not accept antipsychotic LAls if offered ${ }^{19,29}$. Besides, Glazer suggests that psychiatrists assume that LAl antipsychotics present an increased risk of major side effects, like neuroleptic malignant syndrome, extrapyramidal side-effects and tardive dyskinesia ${ }^{30}$. It is possible that these assumptions concur to explain LAls low prescription rates in routine clinical practice 29,30 .

However, the studies examined in this review also showed that patients' perceptions about LAls were multi-faceted and there was often a balance between the perceived disadvantages and advantages of LAls. For example, patients acknowledged that, although on the one hand receiving LAI meant the need to take a leave from work to receive the injection, on the other hand, this guaranteed the continuity of their care under the supervision of a multidisciplinary team. This is in line with Caroli, who reports how patients felt better supported in the management of their symptoms thanks to the regular contact with the health practitioner who administered their LAl injection ${ }^{31}$.

Fear of needles and pain in the site of injection, two of the most cited disadvantages, are mostly reported by LAI-naive patients ${ }^{16,19}$ whereas patients treated with LAIs complain more about everyday worries such as having to ask for leave from work to receive the injection or being unable to schedule a holiday trip because they have to go to the LAI clinic ${ }^{21}$. Perception of LAls is clearly different depending on whether patients have tried or not tried this formulation.

Research shows poor knowledge of long-acting antipsychotics by patients ${ }^{31,32}$. This finding is confirmed in our review: many patients reported that they were not aware of this therapeutic option. Also, patients treated with LAls reported that they were not aware of the real differences between the depot and oral therapy ${ }^{16,19,20}$. Patients that were not familiar with LAls showed curiosity towards this therapeutic option and seemed to want to know more about it. In Rankovic's study, patients who switched from oral to LAls reported remarkable satisfaction, some claiming that they would never go back to oral therapy ${ }^{18}$.

Openness towards LAls emerged in different studies: Cahling et al. report that once informed about the characteristics of LAls, about 20\% of patients showed interest in long-acting therapy ${ }^{28}$. Grover declares that almost $25 \%$ of the patients of his study, having been informed about LAls, may consider them. This is consistent with the only quantitative review on the attitudes of patients towards long-acting antipsychotics, which reported a high rate of acceptance of LAls therapy in patients diagnosed with schizophrenia33. Talking with patients about the benefits and risks of treatment options 
such as LAls can facilitate therapeutic engagement and care within a recovery framework ${ }^{34}$. Patients who perceive a positive therapeutic alliance with their psychiatrist and other staff have improved medication adherence ${ }^{35}$. In this sense, taking LAl medication can be seen as accepting dependency on treatment as protection from relapses and readmissions to hospital ${ }^{15}$. Patients reported trust towards the therapeutic recommendations of their psychiatrists ${ }^{16,20}$. Sometimes, psychiatrists made a therapeutic choice without consulting the patient, for example when patients were too unwell to decide. Regarding this situation, at times patients expressed gratitude towards their physician ${ }^{16,20}$, at other times they reported feeling forced into LAls therapy and that they accepted it because they were told there was no other alternative ${ }^{17,19}$. This is consistent with other work: Patel reports that $47 \%$ of patients treated by LAls have been forced to start the LAl formulation. Sometimes this perceived coercion derives not from the health system providers but from members of the family, partners, or friends, as a sort of "informal coercion"20.

Greater perceived coercion in comparison to oral antipsychotics can contribute to explaining why some psychiatrists and patients consider $\mathrm{LAl}$ to be a more stigmatizing form of treatment ${ }^{36}$. Stigma towards mental disorders can be generalized towards patients, medications and health-care providers; also, patients can stigmatize themselves (self-stigma). In this respect, patients mentioned the need for anti-stigma programs ${ }^{20}$ that should facilitate balanced information about mental disorders and reduce stereotypes, prejudice, and discrimination ${ }^{37}$. Information can also be useful to dispel some myths and misperceptions on LAl therapy, factors that can increase the stigma towards this formulation ${ }^{16,21}$.

Long-acting antipsychotics can also be seen as a step to "returning to normal"15,21 on the road to recovery. Some patients reported an improvement in the quality of their lives after the introduction of LAl15,16. This improvement was made explicit in the relationships with significant others like partners, friends and family ${ }^{20,21}$. Family members, in particular, were not requested to function as a supervision body on the therapy's administration anymore. The greater sense of control on psychotic symptoms, confirmed in other studies ${ }^{38}$, can allow patients to live in a community setting and to have access to material advantages, such as better life conditions and financial support. LAls, in this sense, are seen as a means to break social isolation and to be integrated into society ${ }^{15}$.

Patient improvements also emerged in the workplace setting, where patients perceived themselves as more present and focused, being able to regain abilities they believed to have lost to the illness ${ }^{21}$.

The improvement of the psychotic symptoms reported by many patients ${ }^{15,17,21,23,26}$ allowed them to regain old abilities and to develop new ones. By cultivating skills and abilities, patients were allowed to hope for a cure to their illness, which would allow prevention of relapses and new hospital admissions ${ }^{15,21}$. In this sense, LAl therapy may be seen as an instrument for recovery, a process that helps patients to take back control of their problems and lives, not focusing fully on symptoms but rather emphasizing a sense of hope and a strong belief that it is indeed possible to regain a meaningful life ${ }^{39}$.

It is suggested that LAls should not be seen as the "last resort" therapy but as a therapeutic tool useful for different patients. Samalin identifies two clusters of patients that may take advantage from LAls: Cluster I, composed of patients with a history of relapses and poor compliance to oral therapy. Cluster II, which corresponds to patients with a good level of compliance and high awareness of their illness ${ }^{40,41}$. In particular, patients who belong to Cluster II are those that may choose long-acting formulation if they are given proper information. It is the psychiatrist's duty to make information available for patients, discussing all the medication options, LAls included. In this sense, some authors suggest that LAI antipsychotics should be used for any patient who is undergoing long-term treatment, and not only for those with adherence problems $\mathrm{s}^{42}$. On the other hand, it is important to remember that some patients who are prescribed LAls may relapse and experience significant side-effects ${ }^{34}$. As such, LAI therapy may not be appropriate for all patients but should be considered carefully on a case by case basis.

Of course, therapeutic success in psychosis depends not only on medication but also on the quality of follow-up care $^{43}$. For some patients who are administered LAls, the LAI clinic represents a "safe place" where they receive care and their voice is heard 18,23 . Spending quality time with patients allows developing a sense of community where the patient is not alone but surrounded by key professionals, like nurses, psychiatrists and other mental health-care practitioners. Health-care providers should inform patients about the availability of LAls, their advantages and disadvantages, enabling patients to make an informed choice. Moreover, after the decision to take a LAl, patients should be carefully followed up; the injection alone is certainly not sufficient to meet all their needs ${ }^{20}$.

\section{Limitations}

The included studies are diverse in their settings and populations studied, but most were conducted in Western countries. Studies not published in English or Italian were not included. Therefore, results may not be generalizable to other parts of the world. The quality of the papers is generally high, but studies employed diverse methods of data collection and analysis, and the aims and focus of different studies also varied. Given the variety of populations and the consistency of results, the analysis suggests that the included studies provide a reasonably representative view of the typical experience of taking LAl antipsychotic medication emerging from qualitative research. 


\section{CONCLUSIONS}

Patients typically express mixed views regarding their experience of LAls, which prove to be a valuable tool in the treatment of mental disorders. The findings of our review confirm that there is room for improvement in the process leading to the prescription and administration of this formulation. In particular, the experience of coercion, and the lack of information connected with the prescription as reported by many patients, are particularly concerning. Better information and involvement of service users in the prescription process could also dispel some erroneous beliefs and self-stigma about this type of medication. Another clear point emerging from the review is the need of careful individualized evaluations when considering the potential advantages and disadvantages of LAls, calibrated on the needs of the individual (e.g. sedation, which for some is a negative effect, for others it may prove to be beneficial).

To adequately inform the patient, a good therapeutic relationship plays a decisive role and can strengthen, support and accompany the patient in the choice and acceptance of drug therapy. In fact, patients do not generally express unconditional opposition to LAl, but rather express the need to be adequately informed and supported during the treatment course. In addition, a good doctor-patient relationship can transform the perception of treatment, turning it from a coercive to a supportive and empowering one. Information, individualized choice and a good therapeutic relationship emerge as key elements to bear in mind when considering the prescription of LAls.

\section{INDIVIDUAL CONTRIBUTIONS}

Gian Maria Galeazzi - Conception, project, design, interpretation of results, writing the article, critical revision of the text, and approval of the version to be published.

Gianluca Fiore and Davide Bertani - Project, design, data acquisition, analysis, writing the article, interpretation of results, critical revision of the text, and approval of the version to be published.

Mattia Marchi - Project, design, and approval of the version to be published.

Graça Cardoso - Writing the article, interpretation of results, critical revision of the text, and approval of the version to be published

\section{CONFLICTS OF INTEREST}

The authors have no relevant affiliations or financial involvement with any organisation or entity with a financial interest in, or financial conflict with the subject matter or materials discussed in the manuscript. This includes employment, consultancies, honoraria, stock ownership or options, expert testimony, grants or patents received or pending, or royalties.

\section{ACKNOWLEDGMENTS}

This research received no external funding.

\section{REFERENCES}

1. James SL, Abate D, Abate KH, Abay SM, Abbafati C, Abbasi N, et al. Global, regional, and national incidence, prevalence, and years lived with disability for 354 diseases and injuries for 195 countries and territories, 1990-2017: a systematic analysis for the Global Burden of Disease Study 2017. The Lancet. Elsevier; 2018;392:1789-858.

2. Jaeger M, Rossler W. Attitudes towards long-acting depot antipsychotics: a survey of patients, relatives and psychiatrists. Psychiatry Res. 2010;175:58-62.

3. Valenstein M, Ganoczy D, McCarthy JF, Kim HM, Lee TA, Blow FC. Antipsychotic Adherence Over Time Among Patients Receiving Treatment for Schizophrenia: A Retrospective Review. J Clin Psychiatry. 2006;67:1542-50.

4. Lacro JP, Dunn LB, Dolder CR, Leckband SG, Jeste DV. Prevalence of and risk factors for medication nonadherence in patients with schizophrenia: a comprehensive review of recent literature. J Clin Psychiatry. 2002;63:892-909.

5. Byerly MJ, Nakonezny PA, Lescouflair E. Antipsychotic medication adherence in schizophrenia. Psychiatr Clin North Am. 2007;30:437-52.

6. Hudson TJ, Owen RR, Thrush CR, Han X, Pyne JM, Thapa P, et al. A pilot study of barriers to medication adherence in schizophrenia. J Clin Psychiatry. 2004;65:211-6.

7. Velligan DI, Weiden PJ, Sajatovic M, Scott J, Carpenter D, Ross R, et al. The expert consensus guideline series: adherence problems in patients with serious and persistent mental illness. J Clin Psychiatry. 2009;70(4):1-46.

8. Remington GJ, Adams ME. Depot neuroleptic therapy: clinical considerations. Can J Psychiatry. 1995;40 (Suppl. 1):5-11.

9. Olivares JM, Pinal B, Cinos C. Comparison of long-acting antipsychotic injection and oral antipsychotics in schizophrenia. Neuropsychiatry. 2011;1:275-89.

10. McEvoy JP. Risks versus benefits of different types of long-acting injectable antipsychotics. J Clin Psychiatry. 2006;67(5):15-8.

11. Stevens GL, Dawson G, Zummo J. Clinical benefits and impact of early use of long-acting injectable antipsychotics for schizophrenia. Early Interv Psychiatry. 2016;10:365-77.

12. Barnes TRE, Shingleton-Smith A, Paton C. Antipsychotic long-acting injections: Prescribing practice in the UK. Br J Psychiatry. 2009;195 (52 Suppl): 37-42.

13. West JC, Marcus SC, Wilk J, Countis LM, Regier DA, Olfson M. Use of depot antipsychotic medications for medication nonadherence in schizophrenia. Schizophr Bull. 2008;34:9951001.

14. Noblit GW, Hare RD. Meta-Ethnography: Synthesizing Qualitative Studies. Newbury Park: Sage; 1988.

15. Svedberg B, Backenroth-Ohsako G, Lutzen K. On the path to recovery: Patients' experiences of treatment with long-acting injections of antipsychotic medication. Int J Ment Health Nurs. 2003;12:110-8.

16. Das AK, Malik A, Haddad PM. A qualitative study of the attitudes of patients in an early intervention service towards antipsychotic long-acting injections. Ther Adv Psychopharmacol. 2014;4:179-85.

17. Besenius C, Bradley E, Nolan P. Attitudes of psychiatrists, nurses and service users towards prescribing and administrating depot antipsychotic medication. J Ment Health Train Educ Pract. 2012;7:9-19.

18. Ranković A, Janković S. Problems with the Administration of Antipsychotic Drugs in Depot Formulations in the Treatment of Schizophrenia. Acta Fac Medicae Naissensis. 2018;35:65-72. 
19. Iyer S, Banks N, Roy M-A, Tibbo P, Williams R, Manchanda R, et al. A Qualitative Study of Experiences with and Perceptions regarding Long-Acting Injectable Antipsychotics: Part I - Patient Perspectives. Can J Psychiatry. 2013;58:14-22.

20. de Diego Ruiz H, González González M, Valenti E, García Cabeza I. Patients' perceptions of the use of long-acting injectable antipsychotics. Riv Sper Freniatr. 2019; CXLIII:87-105.

21. Chiu $L-L$, Liu $C-H$, Chu $C-L$, Lin $H-L$, Lii $S-C$. Patients' experiences of long-acting injectable antipsychotics: a qualitative study. Neuropsychiatr Dis Treat. 2019; 15:1797-804.

22. Potkin S, Bera R, Zubek D, Lau G. Patient and prescriber perspectives on long-acting injectable (LAl) antipsychotics and analysis of in-office discussion regarding LAl treatment for schizophrenia. BMC Psychiatry. 2013;13:261.

23. Phillips $L, M c c a n n E$. The subjective experiences of people who regularly receive depot neuroleptic medication in the community. J Psychiatr Ment Health Nurs. 2007;14:578-86.

24. Robinson DG, Subramaniam A, Fearis PJ, Shi R, Walsh M, Hanna LA, et al. Focused Ethnographic Examination of Barriers to Use of Long-Acting Injectable Antipsychotics. Psychiatr Serv. 2020;71:337-42.

25. Patel MX, David AS. Why aren't depot antipsychotics prescribed more often and what can be done about it? Adv Psychiatr Treat. 2005;11:203-11.

26. Blixen C, Lema I, Mbwambo J, Kaaya S, Levin JB, Sajatovic M. Community perceptions of barriers to management of chronic psychotic disorders and knowledge and attitudes about long-acting injectable antipsychotic medication: qualitative study in Dar es Salaam, Tanzania. BJPsych Open. 2020;6,27:1-10.

27. Lai YM, Hong CP, Chee CY. Stigma of mental illness. Singapore Med J. 2001;42:111-4.

28. Cahling L, Berntsson A, Bröms G, Öhrmalm L. Perceptions and knowledge of antipsychotics among mental health professionals and patients. BJPsych Bull. 2017;41:254-9.

29. Manchanda R, Chue P, Malla A, Tibbo P, Roy M-A, Williams R, et al. Long-acting injectable antipsychotics: evidence of effectiveness and use. Can J Psychiatry. 2013;58 (Suppl.1) :5-13.

30. Glazer WM, Kane JM. Depot neuroleptic therapy: an underutilized treatment option. J Clin Psychiatry. 1992;53:426-33.

31. Caroli F, Raymondet P, Izard I, Plas J, Gall B, Delgado A. Opinions of French patients with schizophrenia regarding injectable medication. Patient Prefer Adherence. 2011;5:165-71.
32. Tsang HWH, Fong MWM, Fung KMT, Chung RCK. Perceptions on efficacy and side effects of conventional depot antipsychotics (CDA) and atypical depot antipsychotics (ADA): Psychiatrists versus patients in Hong Kong. Int J Psychiatry Clin Pract. 2010;14:23-32.

33. Walburn J, Gray R, Gournay K, Quraishi S, David AS. Systematic review of patient and nurse attitudes to depot antipsychotic medication. Br J Psychiatry. 2001;179:300-7.

34. Bosanac $P$, Castle DJ. Why are long-acting injectable antipsychotics still underused? BJPsych Adv. 2015;21:98-105

35. Sylvia LG, Hay A, Ostacher MJ, Miklowitz DJ, Nierenberg AA, Thase ME, et al. Association between therapeutic alliance, care satisfaction, and pharmacological adherence in bipolar disorder. J Clin Psychopharmacol. 2013;33:343-50.

36. Patel MX, de Zoysa N, Bernadt M, Bindman J, David AS. Are depot antipsychotics more coercive than tablets? The patient's perspective. J Psychopharmacol . 2010;24:1483-9.

37. Corrigan PW, Watson AC. Understanding the impact of stigma on people with mental illness. World Psychiatry. 2002;:1:16-20

38. Thompson J, Stansfeld JL, Cooper RE, Morant N, Crellin NE, Moncrieff J. Experiences of taking neuroleptic medication and impacts on symptoms, sense of self and agency: a systematic review and thematic synthesis of qualitative data. Soc Psychiatry Psychiatr Epidemiol. 2020;55:151-64.

39. Jacob KS. Recovery Model of Mental IIIness: A Complementary Approach to Psychiatric Care. Indian J Psychol Med. 2015;37:117-9.

40. Samalin L, Charpeaud T, Blanc O, Heres S, Llorca P-M. Clinicians' attitudes toward the use of long-acting injectable antipsychotics. J Nerv Ment Dis. 2013;201:553-9.

41. Silva TFC da, Lovisi GM, Verdolin LD, Cavalcanti MT. Adesão ao tratamento medicamentoso em pacientes do espectro esquizofrênico: uma revisão sistemática da literatura. Jornal Brasileiro de Psiquiatria. 2012;61:242-51.

42. Altamura AC, Fagiolini A, Galderisi S, Rocca P, Rossi A. Integrated treatment of schizophrenia. Journal of Psychopathology. 2015; 21 (Suppl):168-193.

43. Johnson DAW. Historical perspective on antipsychotic long-acting injections. $\mathrm{Br} J$ Psychiatry. 2009;195: 7-12. 